\title{
Fakta Sosial
}

Tim Kerja PSP2M

Memahami posisi seorang Durkheim, sebenarnya seorang murid yang ragu-ragu terhadap pemikiran Comte. Sebagai seorang murid, Durkheim tetap setia pada ajaran Comte yang merupakan perintis teori positivisme Perancis dan juga sekaligus sebagai pencipta istilah "sosiologi". ${ }^{1}$ Pengaruh Comte, pada pemikiran-pemikiran Durkheim, di antaranya yang tampak pada pola "reorganisasi masyarakat" yang dikemukan oleh Comte yang kemudian disempurnakan oleh Durkheim. Durkheim, melihat konsep Comte cenderung bersifat "spekulatif" dan "pragmatis". Durkheim berusaha membenahi kelemahan-kelemahan pemikiran Comte tersebut dengan berusaha tetap menjaga tujuan umum yang dikehendaki oleh Comte.

Pengaruh lain yang tampak pada kepercayaan Durkheim, yang menganut sesuatu yang diyakini terlebih dahulu oleh Comte, yakni kepercayaan akan kemungkinan untuk menunjukkan bahwa masyarakat tunduk pada sebab-sebab alamiah, walaupun Durkheim kurang meyakini rasional total gurunya tersebut akan posisi organisasi ilmiah masyarakat. Dengan dasar ini, Durkheim menolak penafsiran ketat dari hukum Comte tentang kemajuan manusia yang ia anggap sebagai sangat dogmatis dan tidak tepat. Namun Durkheim tetap menyetujui campuran ilmu pengetahuan dan pembaharuan ala comte.

Dengan mengadopsi kerangka organis yang dikemukakan Comte yang berwatak positivis, maka pemikiran Durkheim-pun kental dengan nuansa positivis. Namun tanpaknya pandangan Durkheim berbeda dengan pemikiran Comte. Sebab ciri khas pemikiran positivisme Durkheim adalah usaha satu-satunya untuk mendekati masyarakat sebagai sebuah kenyataan organis yang independen yang memiliki hukum-hukumnya sendiri. Holisme metodologi Durkheim berkaitan dengan sebuah pendirian yang sangat deterministik yang berpendapat bahwa individu-individu tidak berdaya dihadapan pembatasan-pembatasan dari kekuatan-kekuatan sosial yang menghasilkan penyesuaian diri dengan norma-norma sosial atau tingkah laku yang disebabkan oleh norma sosial tersebut. Durkheim, juga mengkombinasikan pengambilan jarak ilmiah dan determinisme kausal dengan kepercayaan bahwa ilmu masyarakat memberi semacam jawaban untuk masalah-masalah etis normatif dari filsafat tradisional.

Implikasi pandangan "positivistik" Durkheim terhadap "moral dalam terapan", dikategorikan sebagai sebuah "fakta sosial". Fakta sosial tersebut didefinisikan sebagai "cara-cara bertindak, berpikir dan merasa", yang "berada di luar individu" dan dilengkapi atau dimuati dengan sebuah kekuatan memaksa yang dapat mengontrol individu. "Fakta sosial" itulah yang akan mempengaruhi setiap tindakan, pikiran dan rasa dari individu. Durkheim, menyatakan apa yang dipikirkan adalah kebiasaan-kebiasaan, adat istiadat dan cara hidup umum manusia sebagai sesuatu yang terkandung dalam institusi, hukum, moral dan ideologi-ideologi politis.

Menurut Durkheim, bagaimanapun sadarnya individu ia harus tetap melaksanakan kewajibankewajiban itu menurut bahasa, adat istiadat, kebiasaan dan hukum masyarakatnya, di mana

\footnotetext{
${ }^{1}$ Comte, filsafat positif-nya, berakar pada kekaguman yang mendalam akan presisi kuantitatif dari ilmu-ilmu alam, khususnya matematika, fisika dan biologi. Comte, berusaha menerapkan metode-metode ini untuk menemukan prinsip-prinsip keteraturan dan perubahan di dalam masyarakat, sehingga menghasilkan sebuah susunan pengetahuan baru yang dapat dipakai untuk mereorganisasikan masyarakat demi perbaikan manusia. Pendekatan ilmiah dan rasionalis Comte, dikombinasikan dengan sebuah perspektif sejarah, terutama dalam "Hukum Kemajuan Manusia” yang menyatakan bahwa semua masyarakat melewati tiga tahapan, yakni : [1] tahapan teologis atau khayal, [2] tahapan metafisik atau abstak, dan [3] tahapan ilmiah atau positif. Masing-masing tahapan tersebut mencakup sikap intelektual yang berbeda-beda. Dalam tahapan teologis, manusia mencari pengetahuan yang absolut dari sifat hakiki kenyataan dan sebab-sebab pertama dan terakhir yang memuncak pada penjelasan segala sesuatu sebagai hasil kehendak Tuhan. Comte, menyatakan bahwa susunan mental yang pada mulanya emosional akan membuka jalan ke sikap metafisis, di mana kekuatan-kekuatan abstrak mengganti kekuatan-kekuatan adi kodrati, tetapi penjelasan-penjelasan masih ditulis dalam pengertian sifat-sifat hakiki, misalnya apabila nilai ekonomi dijelaskan dengan nilai intrinsik benda-benda. Maka, menurutnya, tahapan yang sebagian besar destruktif ini pada gilirannya akan menggiring kepada gaya ilmiah atau positivis di mana pikiran dengan mengesampingkan pencarian penjelasan-penjelasan akhir, memakai observasi atas fenomena untuk menetapkan hukum-hukum dinamika yang mirip dan berbeda-beda. Jadi, menurut Comte, positivisme pengetahuan terbatas pada apa yang tampak oleh panca indera dan dengan demikian pengetahuan hanya menangani hubunganhubungan antasedens dan konsekwens di antara fenomena yang teramati [Lihat : Tom Campbell, Seven Theories,...hIm.149-51].
} 
kesemuanya itu merupakan "fakta-fakta sosial" yang tidak direkayasa atau tidak diciptakannya melainkan ia terpaksa menjalankan dan menyesuaikan dirinya dengan fakta sosial tersebut. Jika individu tidak menyesuaikan diri dengan "fakta sosial" tersebut maka individu tersebut akan menderita konsekuensi-konsekuensi penolakan sosial dan menerima hukuman. Maka dari sini, ada sebuah unsur idealisme sosiologis yang jelas dalam teori Durkheim. ${ }^{2}$

\section{Konsep Fakta Sosial}

Emile Durkheim mengembangkan konsep masalah pokok sosiologi menjadi penting dan kemudian diujinya melalui studi empiris. Secara singkat, Pokok bahasan dari sosiologi adalah studi atas fakta sosial. Fakta sosial didefenisikan sebagai ${ }^{3}$ :

Fakta sosial adalah seluruh cara bertindak, baku maupun tidak, yang dapat berlaku pada diri individu sebagai sebuah paksaan eksternal; atau bisa juga dikatakan bahwa fakta sosial adalah seluruh cara bertindak yang umum dipakai suatu masyarakat, dan pada saat yang sama keberadaannya terlepas dari manifestasi-manifestasi individual.

Asumsi dasar dari pendefenisian Durkheim tersebut adalah bahwa gejala sosial itu riil dan mempengaruhi kesadaran individu serta perilakunya. Gejala sosial (seperti aturan legal, beban moral, bahasa dan konsensus sosial) sebagai sesuatu yang riil/faktual, maka gejala-gejala tersebut dapat dipelajari dengan metode-metode empirik. Oleh sebab itu, dimungkinkan untuk dikembangkannya metode keilmuan dengan gejala/fakta sosial sebagai objek material ilmu tersebut, yaitu ilmu sosiologi.

Kenyataan/fakta sosial tersebut terjadi dalam satu kehidupan bersama/komunitas. Komunitas yang dimaksud di sini adalah komunitas dalam pengertian abad XIX-XX, yang meliputi segala bentuk hubungan yang ditandai oleh tingkat keakraban yang sangat tinggi, kedalaman emosi, komitmen moral, kohesi sosial. Komunitas dibangun atas dasar manusia dalam keutuhannya, bukan perananperanannya yang terpisah-pisah. ${ }^{4}$

\section{Jenis-jenis Fakta Sosial}

Durkheim membedakan dua tipe ranah fakta sosial, yakni fakta sosial material dan fakta sosial non material. Pertama, fakta sosial material, seperti gaya arsitektur, bentuk teknologi, serta hukum dan perundang-undangan, mempunyai kecenderungan untuk lebih mudah dipahami karena dapat diamati secara langsung. Kedua, fakta sosial nonmaterial, merupakan kekuatan moral, seperti nilai dan norma. Meskipun fakta sosial ini bersifat individual (internal) namun dalam interaksi-interaksi individu (masyarakat) maka bentuk dan substansi fakta sosial nonmaterial ini akan "mematuhi" dan tunduk pada interaksi tersebut, bukan oleh individu per individu (pada titik inilah fakta sosial bersifat eksternal). Durkheim memberikan perhatian yang besar terhadap fakta sosial nonmaterial. Fakta sosial nonmaterial ini terdiri dari, paling kurang, empat jenis, yakni: moralitas, kesadaran kolektif, representasi kolektif dan arus sosial.

Moralitas sebagai fakta sosial tidak terlepas dari masyarakat. Pada konteks hidupnya, Durkheim menilai bahwa masyarakat terancam kehilangan ikatan moral (ini disebut "patologi"). Hal ini dimungkinkan karena setiap individu memiliki kecenderungan untuk memuaskan nafsu kegilaan untuk mencapai kepuasan (setiap manusia ingin lebih!). Tanpa ikatan moral (moralitas kolektif) maka individu-individu akan menjadi budak dari kesenangan yang selalu meminta lebih!. Moralitas kolektif dapat tercapai melalui fakta sosial nonmaterial lainnya, seperti kesadaran kolektif yang merujuk pada struktur umum pengertian, norma, dan kepercayaan bersama, kesadaran kolektif ini bersifat terbuka dan dinamis.

Representasi kolektif, dimengerti sebagai gagasan/ daya sosial yang memaksa individu, seperti simbol agama, mitos, dan legenda populer. Hal mana merupakan cara individu merepresentasikan

\footnotetext{
${ }^{2}$ Emile Durkheim, Pendidikan Moral: Suatu Studi Teori dan Aplikasi Sosiologi Pendidikan, terj. Lukas Ginting, Jakarta, Erlangga, t.t, hlm. 35.

${ }^{3}$ Pernyataan ini, selain untuk membedakan dengan displin ilmu psikologi, Durkheim memberikan dua batasan, yakni fakta sosial adalah pengalaman eksternal dan tidak terikat pada individu partikular. Oleh sebaba itulah, Emil Durkheim dikenal sebagai "bapak Sosiologi". Lht. George Ritzer dan Douglas J. Goodman, Teori Sosiologi, Yogyakarta: Kreasi Wacana, 2004, hlm.81.

${ }^{4}$ Djuretna Imam Muhdi, Moral dan Religi Menurut Emile Durkheim dan Henri, Bergson, Yogyakarta: Kanisius, 1994. Hal 30-31
} 
kepercayaan, norma, dan nilai kolektif. Arus sosial yang berhubungan dengan luapan-luapan semangat, amarah, dan rasa belas kasihan yang terbentuk dalam kumpulan publik.

\section{Karakteristik Fakta Sosial}

Durkheim mengemukakan tiga karakteristik fakta sosial (yang membedakannya dengan gejalagejala psikologis), yakni gejala sosial bersifat eksternal terhadap individu, fakta sosial memaksa individu, dan fakta sosial bersifat umum atau tersebar secara meluas dalam masyarakat.

\section{The Division of Labor in Society}

The Division of Labor in Society adalah karya monumental dari Durkheim dan merupakan karya sosiologi klasik yang pertama. Di dalamnya Durkheim memanfaatkan ilmu sosiologi untuk meneliti sesuatu yang disebut sebagai krisis moralitas. Selama hidupnya, Durkkheim merasa adanya krisis moralitas di Perancis akibat adanya revolusi Perancis. Revolusi Perancis telah mendorong orang untuk terpusat pada hak-hak individual, yang merupakan reaksi kontra terhadap dominasi gereja. Durkheim melihat bahwa krisis moralitas (individualisme) berakibat pada pembagian kerja yang memaksa individu-individu tertuntut secara ekonomis dan mengancam moralitas sosial, oleh sebab itulah dibutuhkan moralitas sosial yang baru. Pada titik ini, Durkheim memandang bahwa pembagian kerja tersebut dapat berfungsi positif karena pada akhirnya akan membuahkan solidaritas antara dua orang atau lebih.

\section{Solidaritas Mekanis dan Organis}

Perubahan dalam pembagian kerja memiliki implikasi yang sangat besar bagi struktur masyarakat, Durkheim sangat tertarik dengan perubahan cara di mana solidaritas sosial terbentuk, sehingga perubahan cara-cara masyarakat bertahan dan bagaimana anggotanya melihat diri mereka sebagai bagian yang utuh.

Dalam rangka itu, Durkheim mengklasifikasikan solidaritas menjadi dua tipe yakni solidaritas mekanis dan organis. Masyarakat dalam solidaritas mekanis satu dan padu karena seluruh orang adalah generalis. Berdasarkan keserbasamaan moral dan sosial, solidaritas mekanik ini telah diperkuat oleh displin suatu komunitas. Ikatan dalam masyarakat seperti ini terjadi karena mereka terlibat dalam aktivitas yang sama dan memiliki tanggung jawab yang sama. Solidaritas mekanik ini merupakan dasar kohesi sosial, di mana tingkat perorangan sangatlah rendah. Solidaritas mekanis lahir karena adanya kesamaan-kesamaan dalam masyarakat. Masyarakat dalam solidaritas organis didasarkan atas pembagian kerja dalam masyarakat. Solidaritas organis lahir karena adanya perbedaan-perbedaan yang ada dalam masyarakat.

\section{Dinamika Penduduk}

Pembagian kerja sebagai fakta sosial material diyakini oleh Durkheim mesti dijelaskan oleh fakta sosial yang lainnya. Durkheim meyakini bahwa perubahan solidaritas mekanis menjadi solidaritas organis disebabkan oleh dinamika penduduk. Konsep ini merujuk pada jumlah orang dalam masyarakat dan banyaknya interaksi yang terjadi di antara mereka. Semakin banyak orang berarti makin meningkatnya kompetisi memperebutkan sumber-sumber yang terbatas, sementara makin meningkatnya jumlah interaksi akan berarti makin meningkatnya perjuangan untuk bertahan di antara komponen-komponen masyarakat. Peningkatan pembagian kerja seharusnya menyebabkan orang untuk saling melengkapi, dan bukannya berkonflik satu sama lain. Peningkatan pembagian kerja menawarkan efisiensi yang lebih baik, yang menyebabkan peningkatan sumber daya, menciptakan kompetensi di antaranya secara damai. Masyarakat yang dibentuk oleh solidaritas organis mengarah pada bentuk yang lebih solid dan lebih individual daripada masyarakat yang dibentuk oleh solidaritas mekanis. Di sini, Durkheim memberi muatan positif pada individualitas yang bukannya menghancurkan keeratan ikatan sosial, tetapi malahan dibutuhkan untuk memperkuat ikatan tersebut. 


\section{Hukum Represif dan Restutif}

Fakta sosial material dan fakta sosial nonmaterial sebetulnya saling terkait. Dalam pembahasan sebelumnya, pembagian kerja dan dinamika penduduk adalah fakta sosial material dan solidaritas yang terbentuk di dalamnya adalah fakta sosial nonmaterial. Namun, perhatian Durkheim lebih ditujukan pada fakta sosial nonmaterial, yakni solidaritas tersebut. Untuk mempelajari fakta sosial nonmaterial secara ilmiah, sosiolog harus menguji fakta sosial material yang merefleksikan hakikat dan perubahan fakta sosial nonmaterial. Dalam karya monumentalnya tersebut, Durkheim mencoba untuk mengkaji perbedaan antara hukum dalam masyarakat dengan solidaritas mekanis dengan hukum dalam masyarakat dengan solidaritas organis. Hukum represif membentuk masyarakat dengan solidaritas mekanis, karena moralitas kolektif yang ada menjadi standar untuk menghukum. Pada hukum represif ini, pelanggaran terhadap moralitas bersama akan membuat pelanggar dihukum secara berat. Hukum restitutif (bersifat memulihkan) membentuk masyarakat dengan solidaritas organis. Dalam masyarakat seperti ini, pelanggaran dilihat sebagai serangan terhadap individu, bukan terhadap sistim moral kolektif. Pada masyarakat dengan solidaritas ini, sistim moral kolektif bergeser maknanya, bukan dihilangkan. Hukum yang diterapkan didasarkan atas restitusi.

\section{Normal dan Patologi}

Salah satu hal yang cukup ditekankan dalam gagasan Durkheim dalam bukunya tersebut adalah bahwa seorang sosiolog harus mampu untuk membedakan mana masyarakat sehat dan mana masyarakat yang patologis. Durkheim menyatakan bahwa masyarakat yang sehat bisa diketahui karena sosiolog akan menemukan kondisi yang sama dalam masyarakat lain yang sedang berada pada level yang sama. Jika masyarakat dalam kondisi yang biasanya mesti dimilikinya, maka bisa jadi masyarakat itu sedang mengalami patologi. Durkheim menggunakan ide ini untuk mengeritik beberapa bentuk abnormal yang ada dalam pembagian kerja modern. Ada tiga bentuk perilaku abnormal yakni (1) pembagian kerja anomik, yakni tidak adanya regulasi dalam masyarakat yang menghargai individualitas yang terisolasi dan tidak mau memberitahu masyarakat tentang apa yang harus mereka kerjakan. Perilaku ini mengacu pada kondisi sosial di mana manusia mengalami kekurangan pengendalian moral, (2) pembagian kerja yang dipaksakan, perilaku ini merujuk pada fakta bahwa norma yang ketinggalan zaman dan harapan-harapan bisa memaksa individu, kelompok, dan kelas masuk ke dalam posisi yang tidak sesuai bagi mereka. Tradisi, kekuatan ekonomi atau status bisa menjadi lebih menentukan pekerjaan yang dimiliki, ketimbang bakat dan kualifikasi. (3) pembagian kerja yang dikoordinasi dengan buruk. Disini Durkheim kembali menyatakan bahwa solidaritas organis berasal dari kesalingbergantungan antar mereka. Jika spesialisasi seseorang tidak lahir dari kesalingbergantungan yang meningkat, melainkan dalam isolasi, maka pembagian kerja tidak akan terjadi di dalam solidaritas sosial.

\section{Keadilan}

Agar pembagian kerja dapat berfungsi sebagai moral dan secara sosial menjadi kekuatan pemersatu dalam masyarakat modern, maka ketiga perilaku patologi tersebut harus diminimalisir. Keadilan sosial merupakan kunci bagi proses yang dialami masyarakat modern, yang tidak lagi dipersatukan atas dasar persamaan, tetapi atas dasar perbedaan, di mana perbedaan tersebut mengarah pada sikap kesalingbergantungan.

\section{Bunuh Diri}

Pentingnya arti solidaritas sosial dalam masyarakat bagi seorang individu ditunjukkan oleh Durkheim dalam menganalisis tindakan bunuh diri. Tindakan yang demikian tampak individual tidak dapat dijelaskan melalui cara individual, karena selalu berhubunganan dengan perkara sosial.

Studi Durkheim tentang bunuh diri adalah contoh keterkaitan teori yang dikemukakan oleh Durkheim dengan penelitian. Durkheim memilih studi bunuh diri karena persoalan ini realtif merupakan fenomena konkret dan spesifik, di mana tersedia data yang bagus secara komparatif. Dengan tujuan utama untuk menunjukkan kekuatan ilmu sosiologi. Bunuh diri yang adalah tindakan 
pribadi dan personal dapat dianalisa dengan menggunakan ilmu sosiologi. Durkheim tidak memfokuskan diri pada mengapa orang bunuh diri, tetapi pada mengapa angka bunuh diri dalam satu kelompok (masyarakat) bisa lebih tinggi dari kelompok (masyarakat) yang lainnya. Kesimpulan Durkheim akan hal tersebut adalah bahwa faktor terpenting dalam perbedaan angka bunuh diri akan ditemukan dalam perbedaan level fakta sosial. Kelompok yang berbeda memiliki sentimen kolektif yang berbeda sehingga menciptakan arus sosial yang berbeda pula. Arus sosial itulah yang mempengaruhi keputusan seorang individu untuk bunuh diri.

\section{Daftar Pustaka}

Umanailo, M. C. B. (2014) 'Pierre Bourdieu; Menyikap Kuasa Simbol', OSF. doi: 10.31235/osf.io/4txzu.

Umanailo, M. C. B. (2015) ‘Desa Sebagai Poros Pembangunan Daerah’. doi: 10.31219/osf.io/gp97z.

Umanailo, M. C. B. (2015) Ilmu Sosial Budaya Dasar. 1st edn. Namlea: FAM PUBLISHING. doi: 10.17605/OSF.IO/4HPWC.

Umanailo, M. C. B. (2015) Masyarakat Buru Dalam Perspektif Kontemporer (Kajian Kritis Perubahan Sosial di Kabupaten Buru), Mega Utama. doi: 10.31219/osf.io/6d2g8.

Umanailo, M. C. B. (2016) 'Keterbatasan penggunaan teknologi informasi pada pelayanan dan pembelajaran di universitas iqra buru'.

Umanailo, M. C. B. (2016) Sosiologi Hukum. 1st edn, FAM Publishing. 1st edn. Namlea: FAM PUBLISHING. doi: 10.17605/OSF.IO/KHFNU.

Umanailo, M. C. B. (2017) 'Adakah Ukuran Kemiskinan Buat Masyarakat Di Kabupaten Buru?' doi: 10.31219/osf.io/8ksn2.

Umanailo, M. C. B. (2017) 'Eksistensi Waranggana Dalam Ritual Tayub’. doi: 10.31219/osf.io/vkdb5.

Umanailo, M. C. B. (2017) 'Mengurai Kemiskinan Di Kabupaten Buru'. doi: 10.31219/osf.io/cpgd5.

Umanailo, M. C. B. (2017) 'Mereduksi Multi Partai Untuk Kestabilan Pembangunan Nasional'. doi: 10.31219/osf.io/e37fp.

Umanailo, M. C. B. (2017) 'Penciptaan Sumberdaya Manusia Yang Berkarakter'. doi: 10.31219/osf.io/xnc93.

Umanailo, M. C. B. (2018) 'Studi pada Masyarakat Desa Waimangit Kabupaten Buru', SOCA, 12(12), pp. 6374. doi: 10.24843/SOCA.2018.v12.i01.p05.

Umanailo, M. C. B. and Yatno, T. (2015) Kajian dan Analisis Sosiologi Dalam Bentuk Kumpulan Essay, Makalah dan Opini. doi: 10.31219/osf.io/jd2qp. 